\title{
Tanzanian Secondary School Learners' Beliefs about EFL Learning, Teaching and Testing: Exploratory
}

\author{
Account \\ Zelda Elisifa Sam \\ Department of Linguistics and Literary Studies \\ Open University of Tanzania, Dar es Salaam, Tanzania \\ E-mail: Zelda.elisifa@ out.ac.tz
}

Received: April 22, 2018 Accepted: May 30, 2018 Published: June 1, 2018

doi:10.5296/jsel.v6i1.13234 URL: https://doi.org/10.5296/jsel.v6i1.13234

\begin{abstract}
The current study explored EFL secondary school learners' beliefs about language teaching, learning and testing in Tanzania. Specifically, it sought to find out the EFL learners' beliefs about language assessment, explore the EFL learners' beliefs about language learning and establish degree of EFL learner variability in their beliefs about language teaching. The study involved 48 secondary school learners, 36 (75\%) males and 12 (25\%) females. From these 20 (all boys) (50\%) were from a private secondary school in Temeke and the rest (16 boys and all 12 girls) from another secondary school in Kinondoni District, Dar es Salaam, Tanzania. Data were collected via a questionnaire, which was one and only tool for data gathering and it consisted of 25 items, five on language assessment, 9 on language teaching and 11 on language learning to which the respondents were asked to react and register their level of agreement about pre -developed assertions. Findings showed that while the learners differed in their beliefs about language teaching, a grand majority shared a belief about primacy of grammar teaching and on role of teacher in error correction and disfavoured communicative language teaching. The same was the case for language assessment where the most shared belief was testing grammar and correcting errors. It is concluded that these set of beliefs are hinged upon years of grammar-focussed teaching in Tanzania which still characterize language teaching in Tanzania despite the introduction of communicative language teaching approach in the national language curriculum more than ten years ago.
\end{abstract}

Keywords: China insurance industry, Foreign fund, Challenge 


\section{Introduction}

In recent times a shift has been made in Second Language Acquisition (SLA) from teacher-centred language teaching to student-cantered learning. As a consequence, the focus of research in language learning and teaching has also shifted towards the learner as an individual. This learning individuality deserves special emphasis as Benson (2005:5) reiterates "learners are individuals and that their individuality may have significant consequences for their learning". In that framework of thought, there have been studies conducted from the learner's perspective which reflects the 'truth' as viewed from the learners' mind-sets (Riley, 1997). Since the mid-1980s, the role played by learner beliefs in second language learning has been attracting considerable research interest in Applied Linguistics. For instance, Horwitz's (1987) pioneering study provoked considerable research quest about the nature of beliefs held by language learners. From that time onwards, a lot of studies have been conducted in the subject matter in different SL/FL learning contexts (e.g. Park, 1995; Riley, 1997; Banya and Cheng, 1997; Gaies, 1998; Sakui and Gaies, 1999; Mori, 1999; Horwitz, 1999; Benson and Lor, 1999; White, 1999; Breen, 2001; Alanen, 2003; Ferreira, 2003; Dufva, 2003; Kramsch, 2003; Kalaja, 2003; Kalaja and Ferreira, 2003; Williams et al., 2004; Bernat and Gvozdenko, 2005; Bernat, 2004; Gabillon, 2005; Benson and Nunan, 2005; Nikitina and Furuoka, 2007; Ellis, 2008; Loewen et al., 2009; Pazaver and Wang, 2009; Ferreira and Kalaja, 2011; Mohammad and Shokrpour, 2012; Ghabanchi and Meidani, 2012; Saleh, 2012; Maftoon and Shakouri, 2013; Yoshida, 2013; Akbari and Karimi, 2013).

Learner beliefs have thus been of a great interest for many scholars from diverse disciplines. The issue of learners' beliefs, influenced by different theories and conceptualizations, has been mainly examined not only from cognitive psychology but also from a socio-cultural perspective. While cognitive research into learner beliefs recognised the individuality of human cognition (Williams and Burden, 1997), research into learner beliefs from a sociocultural perspective, stressed the social nature of beliefs which are context-dependent, that is, constructed in a social context (see Chawhan and Oliver, 2000; Kim-Yoon, 2000; Woods, 2003; Alanen, 2003; Dufva, 2003).

However, to what extent beliefs are mental and individual but also social and cultural has been the major debate in the research literature. These days, many scholars actually support the dual nature of beliefs (Alanen, 2003; Dufva 2003). Although learner beliefs constitute an individual difference variable notably different from the other individual difference factors (Ellis, 2008), the fact is that beliefs, like other individual difference variables such as language aptitude and motivation, influence both the process and product of language learning (Ellis, Ibid.).

Generally, learner beliefs -or personal opinions- or pre-conceived ideas- are described as an important individual difference variable in L2 learning which "form the basis for our personal decisions as to how to proceed" (McDonough, 1995:9) and, accordingly, these predispositions to action may somehow account for learning progress and ultimate achievement (Breen, 2001; Dörnyei, 2005; Ellis, 2008). Victori and Lockhart (1995:224) define learner 
beliefs as "general assumptions that students hold about themselves as learners, about factors influencing language learning, and about the nature of language learning and teaching". More specifically, Alexander and Dochy (1995) posit that beliefs are viewed as idiosyncratic and subjective. In this sense, Gaies (1998) proposes three characteristics of beliefs about language learning: a) beliefs are subjective understandings, b) beliefs are relatively stable over time and c) beliefs are idiosyncratic, that is, belief systems are unique to individuals. Additionally, learner beliefs are both dynamic and situation specific, that is, beliefs change over time as a product of new situational experiences (Sakui and Gaies, 1999; Ellis 2002, 2008; Tanaka, 2004; Zhong, 2008). This proves abundance of research in the area of learner beliefs though in generic and causal ones between belief and performance.

\section{Current Study}

\subsection{Statement of the Problem}

If, as described above, beliefs influence the actions that learners perform to learn an L2, they cannot be ignored by teachers. Little learning is likely if there is a mismatch between the teacher's and the students' belief systems. This suggests the need for teachers to make their own beliefs about language learning explicit, to find out about their students' beliefs, to help their students become aware of and to evaluate their own beliefs and to address any mismatch in their belief systems and those held by their students.

Although learner beliefs are actually viewed as an important individual difference variable in L2 learning (Dörnyei, 2005; Ellis, 2008), the fact is that learner beliefs about language teaching, learning and testing have remained relatively low, notably in English as Foreign Language (EFL) contexts in Tanzania. As indicated above, research into learner beliefs is anticipated to broaden our understanding of SLA. Accordingly, we need to discover what students (notably in EFL context) actually expect from language classes and believe about their learning so as to account for how they actually approach and face second language learning in foreign language context. Thus, more research is needed in the context of EFL to get richer insights of learner beliefs. This study thus sought to explore EFL secondary school learners' beliefs about language teaching, learning and testing in Tanzania.

\subsection{Research Objectives}

The study will be guided by the following objectives

i) To find out the EFL learners' beliefs about language assessment.

ii) To explore the EFL learners' beliefs about language learning.

iii) To establish degree of EFL learner variability in their beliefs about language teaching.

\subsection{Materials and Respondents}

The current study involved 48 secondary school learners, 36 (75\%) males and 12 (25\%) female. From these 20 (all boys) (50\%) were from a private secondary school in Temeke and 
the rest (16 boys and all 12 girls) from another secondary school in Kinondoni District. Both districts are found within Dar es Salaam region. In that sense the study composed respondents from within urban setting only. All these learners were in their third year of secondary education which is believed to occupy a mid-point in the entire secondary education cycle in Tanzania it is also a stage where learners are believed to have developed sure stance or belief systems that guide or regulate their extents of ultimate attainment of English as a foreign language.

These were served with a questionnaire each. This questionnaire, which was a sole tool for this data gathering, consisted of 25 items, five on language assessment, 9 on language teaching and 11 on language learning. The learners were asked to react and register their level of agreement about pre-developed assertions. The data were then posted to SPSS software for running frequencies aid the results were summarized in tables.

\subsection{The Findings}

The findings are presented according to the chronology of research objectives states earlier in this report, starting with beliefs on language assessment, followed by language learning and finally by beliefs on language teaching.

\subsubsection{EFL Learners' Beliefs about Language Assessment}

Brown (2001) defines assessment as a method of measuring a person's ability or knowledge in a given domain (in this context, English). He adds that a test is an instrument or procedure designed to elicit performance from learners with the purpose of measuring their attainment of specified criteria. The learners' beliefs in this aspect of language were variously responded to by the respondents as summarised in table 1 below.

Table 1. Beliefs about Language Assessment

\begin{tabular}{|llllll|l|c|}
\hline S/n & BELIEF & $\begin{array}{l}\text { Totall } \\
\mathbf{y} \\
\text { Agree }\end{array}$ & $\begin{array}{l}\text { Partiall } \\
\mathbf{y} \\
\text { Agree }\end{array}$ & $\begin{array}{l}\text { Partiall } \\
\mathbf{y} \\
\text { Disagr } \\
\text { ee }\end{array}$ & $\begin{array}{l}\text { Totally } \\
\text { Disagre } \\
\text { e }\end{array}$ & $\begin{array}{c}\text { Tota } \\
\text { I }\end{array}$ \\
\hline $\mathbf{1}$ & $\begin{array}{l}\text { It's OK to guess and produce an } \\
\text { ungrammatical sentence in order to } \\
\text { make yourself understandable in the } \\
\text { classroom }\end{array}$ & 16 & 4 & 16 & 48 \\
\hline $\mathbf{2}$ & $\begin{array}{l}\text { Testing students on what has been } \\
\text { taught in class is more important } \\
\text { than testing their overall language } \\
\text { development }\end{array}$ & 18 & 17 & 3 & 10 & 48 \\
\hline $\mathbf{3}$ & $\begin{array}{l}\text { It is essential to correct most errors } \\
\mathbf{4}\end{array}$ & $\begin{array}{l}\text { I dislike it when I am corrected in } \\
\text { class }\end{array}$ & 15 & 6 & 9 & 18 & 48 \\
\hline
\end{tabular}




\begin{tabular}{|l|l|l|l|l|l|l|}
\hline $\mathbf{5}$ & $\begin{array}{l}\text { The effective English language } \\
\text { teacher grades written and spoken } \\
\text { language } \\
\text { predominantly for grammatical }\end{array}$ & 25 & 15 & 4 & 4 & 48 \\
\hline
\end{tabular}

Table 1 above shows 5 beliefs about language assessment and error correction. Belief no. 5 about perceived effective language teacher whose grading is geared towards grammatical accuracy was the most agreed to. To this belief, 40 respondents (83\%) - out of whom 25 (52\%) strongly agreed with it and $15(21 \%)$ partially agreed with it, registering their being believers in grammatical competence as key to the mastery of the language.

Unlike of the afore analysed belief, there was an assertion on guessing and risk taking in producing grammatical sentences. Hence the concern is on meaning - making rather than fear of ungrammaticality. This had $16(23 \%)$ strongly agreeing and $12(25 \%)$ partially concurring with the $28(58 \%)$ the assertion. What this means is that the respondents were divided since the remaining 20 (42\% were not believers in risk taking; they were therefore perfectionist in their approach to language accuracy. This latter group would not achieve very high language proficiency in as fast a rate as required.

Another set of belief was on test content area (item 2) to which 35 respondents indicated their concurrence with the assertion that it is better to delimit the test content areas to what was taught in class and not include overall language ability (popular as global proficiency) these students see language teaching as a declarative process - focusing an notions and abstractions for memorisation and analysis (like any other subject). This kind of belief system is equated with the traditional teaching of discrete points of grammar in separate lessons, and as such also includes the approach advocated by DeKeyser (1998). However, the minority (13 of them, similar to 27\%) who did not agree the assertion view language teaching as geared towards attaining global ability for language. This latter group's belief orientation is practical and realistic if we take language as serving a functional medium of communication. This is popular as focus on form, in which the students' attention to linguistic elements as they arise incidentally in lessons whose overriding focus is on meaning or communication (Long, 1991). It is also in line with the current curricular orientation in Tanzania which focuses on communicative language learning.

The forth belief item was on how much of error correction is to be involved. To this, 30 (63\%) respondent strongly agreed and $5(10 \%)$ partially agreed with the assertion that it is essential to correct most of errors. This aspect of error correction, controversial as is, is helpful in the 'noticing effect, whereby learners encounter gaps between what they want to say and what they are able to say, and so they notice what they do not know or only know partially in this language (Swain and Lapkin, 1995).

Equally controversial among applied linguists is the last assertion (item 4). This is about the emotive aspect of the correct, notably in its face - threatening potential. To this assertion, simple majority (27, which is $56 \%$ ) did not concur with the dislike of being corrected in class, 
unlike Elisifa's (2016) respondents the majority of whom indicated their displeasure with public error correction. However, it is worth heeding cautions given by Tedick and de Gortari (1998) that error correction, if it is has to be employed instantly, should be done in a way that will not cause inhibition or apprehension to the learner.

\subsubsection{Learners' Beliefs about Language Learning}

This aspect of learner belief system was hinged upon the observation by Stevick (1980) what goes on inside learners, which includes learners ${ }^{\text {ee }}$ beliefs, seems to have a strong impact on learners' learning process. Additionally, Wenden (1986) observes that in studying language learners beliefs, the learners are able to talk about the language, their proficiency in language, the outcome of their language learning endeavours, their role in the language learning process, and the best approach to language learning. In the current study the learners were not homogeneous in their concurrence with different aspects of language learning as illustrated in table 2 .

Table 2. Beliefs about Language Learning

\begin{tabular}{|c|c|c|c|c|c|c|}
\hline s/ & BELIEF & $\begin{array}{l}\text { Totall } \\
\mathbf{y} \\
\text { Agree }\end{array}$ & $\begin{array}{l}\text { Partiall } \\
\text { y } \\
\text { Agree }\end{array}$ & $\begin{array}{l}\text { Partiall } \\
\text { y } \\
\text { Disagr } \\
\text { ee }\end{array}$ & $\begin{array}{l}\text { Totally } \\
\text { Disagr } \\
\text { ee }\end{array}$ & $\begin{array}{l}\text { Tota } \\
1\end{array}$ \\
\hline 1 & $\begin{array}{l}\text { There should be more formal study of } \\
\text { grammar in my English classes. }\end{array}$ & 34 & 9 & 3 & 2 & 48 \\
\hline 2 & $\begin{array}{l}\text { Learning English is mostly a matter of } \\
\text { learning a lot of grammar rules. }\end{array}$ & 30 & 12 & 3 & 3 & 48 \\
\hline 3 & $\begin{array}{l}\text { It is necessary to know about } \\
\text { English-speaking cultures in order to } \\
\text { speak English well. }\end{array}$ & 18 & 16 & 8 & 6 & 48 \\
\hline 4 & $\begin{array}{l}\text { I usually keep grammar rules in mind } \\
\text { when I write an English text. }\end{array}$ & 31 & 8 & 3 & 6 & 48 \\
\hline 5 & $\begin{array}{l}\text { I rather say nothing than make } \\
\text { mistakes. }\end{array}$ & 6 & 11 & 9 & 22 & 48 \\
\hline 6 & $\begin{array}{l}\text { You shouldn't say anything in English } \\
\text { until you can say it correctly. }\end{array}$ & 12 & 8 & 9 & 19 & 48 \\
\hline 7 & $\begin{array}{l}\text { The formal study of grammar is } \\
\text { essential to eventual mastery of } \\
\text { English. }\end{array}$ & 29 & 9 & 3 & 7 & 48 \\
\hline 8 & $\begin{array}{l}\text { Generally speaking, students' } \\
\text { communicative ability improves most } \\
\text { quickly if they study and practice the } \\
\text { grammar of English. }\end{array}$ & 32 & 5 & 3 & 8 & 48 \\
\hline 9 & I like the study of grammar & 36 & 7 & 3 & 2 & 48 \\
\hline 10 & $\begin{array}{l}\text { I believe my English improves most } \\
\text { quickly if I study and practice the }\end{array}$ & 39 & 6 & 1 & 2 & \\
\hline
\end{tabular}




\begin{tabular}{|l|l|l|l|l|l|l|}
\hline & grammar & & & & & \\
\hline 11 & $\begin{array}{l}\text { Activities that focus on the exchange } \\
\text { of meaning between to speakers are } \\
\text { more important than activities that } \\
\text { focus on the manipulation of } \\
\text { grammatical forms. }\end{array}$ & 23 & 6 & 10 & 48 \\
\hline
\end{tabular}

As per table 2 above, the most popular belief about language teaching is a preference of grammar instruction over language practice involving oral presentation. This was agreed with by $40(83 \%)$ out of whom $24(60 \%)$ showed total agreement while $16(33 \%)$ agreed any partially. Related to this, and which ranked second in popularity, is a belief about preference for grammar instructions over class discussions. To this 38 (79\%) indicated their concurrence with it, out of whom $32(67 \%)$ fully concurred whereas $6(12 \%)$ concurred but with sure reservations.

This overwhelming majority believing that grammar instruction is more important than oral practice and interactive use of language has two implications. First, the communicative language teaching, which had been in operational for sometimes row is perceived as not rewarding (see Lyimo, 2008, Ndulika 2016). Therefore, learners have nostalgia for the good old days, admiring the English of senior citizens who were taught under traditional grammar instructions. Secondly, these learners see testing of language as not been as communicative in approach as it is the case for the teaching. As a result they feel they would rather be given grammar instructions and drills as suggested by behaviourists like Skinner (1957) and Watson, (1930) than engage in what cumin (2002) refer to as basic interpersonal communication skills (BICS). This belief system is highly congruent with 31(65\%) of respondents to item 9 to which they concurred with the assertion that teaching about English grammar so, these respondents adamantly believe in what Long (1991) Calls form-focused instructions rather than instructions focusing on meaning. Most likely, they were the same 33 (69\%), who other fully concurred (16 of them, similar to $37 \%$ ) or partially concurred (17 of them, similar to $36 \%$ ) with the teaching of grammar deductively rather than inductively. However, a confusion arose as 35 (73\%) concurred with inductive grammar teaching) as to which of the two ought to be the ideal teaching of grammar due to overlaps of respondents numbers.

However, there are some (37 which is $77 \%$ and hence overlapping of respondents in their beliefs notwithstanding) who were the opposed. These either fully agreed or partially agreed with the assertion that effective foreign language teachers involve role play among learners (item 2 of table?). These learners are subscribers to communicative language teaching approach - which is official in Tanzanian EFL teaching and which focuses on language use rather than language form. This belief system has its discipleship from Dell Hymes' (1976) belief that there are rules of use without which rules of grammar would be useless.

\subsubsection{Learners' Beliefs about Language Teaching}

Teaching is the facilitation of learning a language, and, as Johnson (1999) puts it, beliefs 


\section{Ml Macrothink}

about it are such powerful influences that affect the way teachers carry out every aspect of their work because they act as lenses which filter every interpretation and decision teachers make. It is from such backdrop that the learners in this study were asked to show their agreement with assertions provided in the questionnaire. Their responses are summarised in table 3 .

Table 3. Beliefs about Language Teaching

\begin{tabular}{|c|c|c|c|c|c|c|}
\hline $\begin{array}{l}\text { s/ } \\
\mathbf{n}\end{array}$ & BELIEF & $\begin{array}{l}\text { Totall } \\
\mathbf{y} \\
\text { Agree }\end{array}$ & $\begin{array}{l}\text { Partiall } \\
\text { y Agree }\end{array}$ & $\begin{array}{l}\text { Partial } \\
\text { ly } \\
\text { Disagr } \\
\text { ee }\end{array}$ & $\begin{array}{l}\text { Totally } \\
\text { Disagr } \\
\text { ee }\end{array}$ & $\begin{array}{l}\text { Tota } \\
1\end{array}$ \\
\hline 1 & $\begin{array}{l}\text { I prefer grammar instruction over oral } \\
\text { presentations }\end{array}$ & 24 & 16 & 5 & 3 & 48 \\
\hline 2 & $\begin{array}{l}\text { The effective foreign language } \\
\text { teacher uses student-student role play } \\
\text { situations from the beginning of } \\
\text { elementary language instruction }\end{array}$ & 13 & 24 & 2 & 9 & 48 \\
\hline 3 & $\begin{array}{l}\text { My teacher prefers teaching grammar } \\
\text { rather than teaching communicative } \\
\text { skills }\end{array}$ & 15 & 17 & 7 & 9 & 48 \\
\hline 4 & $\begin{array}{l}\text { The Effective English Language } \\
\text { teacher teaches grammar inductively } \\
\text { (i.e. gives examples before } \\
\text { grammatical rule) }\end{array}$ & 19 & 12 & 7 & 10 & 48 \\
\hline 5 & $\begin{array}{l}\text { The effective English teacher teaches } \\
\text { grammar deductively (i.e. gives } \\
\text { grammatical rule before examples) }\end{array}$ & 16 & 17 & 5 & 10 & 48 \\
\hline 6 & $\begin{array}{l}\text { The teacher includes discussion about } \\
\text { the nature of language teaching as a } \\
\text { regular part of the instruction }\end{array}$ & 24 & 11 & 4 & 9 & 48 \\
\hline 7 & $\begin{array}{l}\text { I prefer grammar instruction to class } \\
\text { discussions }\end{array}$ & 32 & 6 & 3 & 7 & 48 \\
\hline 8 & $\begin{array}{l}\text { I know what teaching method the } \\
\text { teacher adopts and the rationale } \\
\text { behind it. }\end{array}$ & 15 & 22 & 6 & 5 & 48 \\
\hline 9 & $\begin{array}{l}\text { Teaching about English culture is not } \\
\text { as important as teaching grammar } \\
\text { and vocabulary. }\end{array}$ & 16 & 15 & 7 & 10 & 48 \\
\hline
\end{tabular}

Table 3 consists of nine items on beliefs on language teaching, seven of them focussing on 
grammar teaching and use of grammatical rules, and two on language use. The most popularly shared belief among the respondents, with 45 (94\%) of respondents totally and partially agreeing with, is that language use improves very fast if one studies and practices grammar. This type of belief is common for those who see language as an ideal, error - free communicative enterprise and a mirror of excellence in linguistic encoding and decoding.

Related to these are two assertions both of which were concurred with by 43 (90\%). The first was item 9, which is the point of departure for all beliefs related to grammar focused language teaching. This item asserted the learner's intrinsic motivation for the learning of grammar. Without interest for language learning (and in this context grammar learning), success is likely to be low. The second is items in the list which shifts from learner's overall inner drive for learning grammar into a desire for pedagogical bias towards the same. This is similar to what Brown (2000) called task-based language learning motivation which is based on unique interest to particular aspects or areas of language e.g. grammar and vocabulary over others. An item that is almost similar to the items 1 and 9 and serves as concussion by the adherents of primacy of grammar in language acquisition is item No.3. This item was totally agreed with by $30(63 \%)$ and partially agreed with by $12(25 \%)$ of respondents. In other words, only $12 \%$ of the respondents did not believe in grammar as key to mastery of English. Also a fair majority (31 agreeing totally and 8 partially agreeing, which is $65 \%$ and $17 \%$, respectively) also shared a belief that in learning the language skill of writing it is a norm to keep rules of grammar affront. Also there are beliefs that overall ability of one's use of language improves as one practices grammatical rules (item no. 8) and that such mastery is brought about by of a formal study of language. These two beliefs were agreed with by 37 (77\%) and $38(79 \%)$ respondents, respectively. However, the fear of making mistakes as communicated in items 5 and 6 were not agreed with by $31(65 \%)$ and $28(58 \%)$ of the respondents, respectively.

Nonetheless, two items that focused on usage aspects of language were also favoured by a significant number of respondents. The first in this category is item 3 which stress the importance of cultural pragmatic aspects English as an integral part of gaining oral proficiency in the language. The second is importance of speakers being integral part the speech community for them to gain communicative competence. To the former 34 (71\%) was either totally agreed with or partially agreed with by the respondents, while to the latter 32 $(67 \%)$ agreed (either fully or partially) with the assertion.

\section{Conclusion}

The findings have shown how diverse EFL learners in this study were in their beliefs about language teaching, learning and assessment. However, they shared views on primacy of grammar and focus on errors both in the teaching and assessment of language. Therefore, one can certainly agree that the learners' beliefs shape the world in which they operate and how they learn any additional language, notably in foreign language context as is the case for English in Tanzania. In addition, Abraham and Vann (1987:95) observe that learners' philosophy of language refer to "beliefs about how language operates, and, consequently, 


\section{Macrothink

how it is learned". This philosophy guides the learners approach to language learning. Ferreira (2006) adds that beliefs about second language acquisition will directly impact learners' attitudes, motivation and learning strategies.

However, these beliefs are usually shaped by students' and teachers' backgrounds since they are formed through interactions with others, own experiences and the impact of the environment around them. This is the case in Tanzania where the traditional mode of teaching (Grammar-focused teaching) has been in operation for many years even though the government adopted communicative language teaching in its language curriculum more than a decade ago.

\section{Acknowledgement}

The research is was funded by Open University of Tanzania under its Directorate of Postgraduate Studies and Publication

\section{References}

Abraham, R. G., \& Vann, R. J. (1987). "Strategies of two Language Learners: A Case Study". In A. Wenden, \& J. Rubin (Eds.), Learner strategies in Language Learning (pp. 85102). London, UK: Prentice Hall.

Akbari, R., \& Karimi, M. N. (2013). "EFL students' proficiency outcomes: What do epistemological beliefs have to offer?", The Asian EFL Journal, 15(3), 1-17.

Alanen, R. (2003). A Sociocultural Approach to Young Language Learners' Beliefs about Language Learning. In P. Kalaja and A.M. Ferreira (eds.), Beliefs about SLA: New Research Approaches. Netherlands: Kluwer Academic Publishers, pp. 55-85.

Alexander, P. A., \& Dochy, F. (1995). Conceptions of Knowledge and Beliefs: A Comparison across Varying Cultural and Educational Communities. American Educational Research Journal, 32, 413-442.

Bailey, K., Curtis, A., \& Nunan, D. (2001). Pursuing Professional Development: The Self as Source. Boston, MA: Heinle \& Heinle.

Banya, K., \& Cheng, M. (1997). Beliefs about Language Learning-A study of Beliefs of Teachers' and Students' Cultural Settings. Paper presented at the Annual Meeting of the Teachers of English to Speakers of Other Languages (31st, Orlando, FL, March 11-15, 1997). ED411 691.

Benson, P. (2005). "(Auto)biography and Learner Diversity", in P. Benson and D. Nunan (eds.), Learner's Stories: Difference and Diversity in Language Learning. Cambridge: Cambridge University Press, 4-21.

Benson, P., \& Lor, W. (1999). Conceptions of Language and Language Learning, System, 
27(4), 459-472.

Benson, P., \& Nunan, D. (eds.) (2005). Learners' Stories: Difference and Diversity in Language Learning. Cambridge: Cambridge University Press.

Bernat, E. (2004). Investigating Vietnamese ESL Learners' Beliefs about Language Learning. EA Journal, 21(2), 40-54.

Bernat, E., \& Gvozdenko, I. (2005). Beliefs about Language Learning: Current Knowledge, Pedagogical Implications, and New Research Directions. TESL-EJ, 9(1), 1-21.

Borg, S. (2006). Teacher Cognition and Language Education. London, UK: Continuum.

Breen, M. P. (ed.). (2001). Learner Contributions to Language Learning: New directions in Research. Harlow, Essex: Pearson Education Limited.

Brown, Douglas. (2001). Teaching by Principles: An Interactive Approach to language Pedagogy. New York: Addison Wesley Longman, Inc.

Chawhan, L., \& Oliver, R. (2000). What Beliefs do ESL Students Hold about Language Learning? TESOL in Context, 10(1), 20-26.

Collier, V. (1995). Promoting Academic Success for ESL Students. Understanding Second Language Acquisition for School. New Jersey, NJ: Teachers of English to Speakers of Other Languages-Bilingual Educators.

Creswell, J. W., \& Plano Clark, V. L. (2011). Designing and Conducting Mixed Methods Research (2nd ed.). Thousand Oaks, CA: SAGE Publications, Inc.

Cumming, A. (2004). Broadening, Deepening, and Consolidating. Language Assessment Quarterly, 1(1), 5-18.

DeKeyser, R. M. (1998). Beyond Focus on Form: Cognitive Perspectives on Learning and Practising second language grammar. In Doughty, C. and J. Williams (eds.) Focus on Form in Classroom Second Language Acquisition. Cambridge: Cambridge University Press.

Deng, Z. (2004). Beyond Teacher Training: Singaporean Teacher Preparation in the Era of New Educational Initiatives. Teaching Education, 15(2), 159-173.

Dörnyei, Z. (2005). The Psychology of the Language Learner: Individual Differences in Second Language Acquisition. London: Routledge.

Dufva, H. (2003). Beliefs in dialogue: A Bakhtinian View. In P. Kalaja and A.M. Ferreira (eds.), Beliefs about SLA: New Research Approaches. Netherlands: Kluwer Academic Publishers, 131-152.

Ellis, R. (2002). A metaphorical analysis of learner beliefs. In P. Burmeister, T. Piske and A. Rohde (eds.), An Integrated View of Language Development: Papers in Honor of Henning Wode. Trier, Germany: Wissenschaftlicher Verlag, 163-179.

Ellis, R. (2008). Learner Beliefs and Language Learning. Asian EFL Journal, 10(4), 7-25. 


\section{$\triangle$ Macrothink}

Journal for the Study of English Linguistics

ISSN 2329-7034

2018, Vol. 6, No. 1

Ellis, R., \& Barkhuizen, G. (2005). Analysing Learner Language. Oxford, UK: Oxford University Press.

Ferreira, A. M. (2006). Researching Beliefs about SLA: A Critical Review. In P. Kalaja, \& A. M. Ferreira (Eds.), Beliefs about SLA: New Research Approaches New York, NY: Springer Science Business Media, (pp. 7-33).

Ferreira, A.Ma (2003). Researching beliefs about SLA: A critical review. In P. Kalaja and A. $\mathrm{M}^{\mathrm{a}}$ Ferreira (eds.), Beliefs about SLA. New Research Approaches. The Netherlands: Kluwer Academic Publishers, 7-33

Ferreira, A.M ${ }^{\text {a }}$ \& Kalaja, P. (2011). Introduction to Beliefs about SLA Revisited, System, 39(3), 281-289.

Gabillon, Z. (2005). L2 Learner's Beliefs: An Overview, Journal of Language and Learning, $3(2), 233-260$.

Gaies, S. (1998). Japanese Language Learners' Perceptions of Methodological alternatives.

Ghabanchi, Z., \& Meidani, E.N. (2012). Beliefs about language learning and strategy use: the case of Iranian non-English majors, World Journal of English Language, 2(1) 21-30.

Horwitz, E. (1988). The Beliefs about Language Learning of Beginning University Foreign Language Students. The Modern Language Journal, 72(3), 283-294.

Horwitz, E. K. (1987). Surveying Student Beliefs about Language Learning. In A.L. Wenden and J. Rubin (eds.), Learner Strategies in Language Learning. Englewoods Cliffs, NY: Prentice Hall, pp.119-132.

Horwitz, E. K. (1999). Cultural and Situational Influences on Foreign Language Learners' Beliefs about Language Learning: A Review of BALLI Studies, System, 27(4), 557-576.

Hymes, Dell. (1976). Foundations in Sociolinguistics: An Ethnographic Approach (8th ed.). Philadelphia: University of Pennsylvania Press.

Johnson, K. E. (1999). Understanding Language Teaching: Reasoning in Action. Boston, MA: Heinle \& Heinle Publishers.

Kalaja P., \& Ferreira, A.M (Eds.) (2003). Beliefs about SLA. New Research Approaches. The Netherlands: Kluwer Academic Publishers.

Kalaja, P. (2003). Research on Students' Beliefs about SLA within a Discursive Approach. In P. Kalaja and A.M. Ferreira (eds.), Beliefs about SLA: New Research Approaches. Netherlands:Kluwer Academic Publishers, 131-152.

Kim-Yoon, H. (2000). Learner Beliefs about Language Learning, Motivation and their Relationship: A Study of EFL Learners in Korea, Unpublished doctoral dissertation. The University of Texas at Austin, TX.

Kramsch, C. (2003). Metaphor and the Subjective Construction of Beliefs. In P. Kalaja and A.M. Ferreira (eds.), Beliefs about SLA: New Research Approaches. London: Cambridge 
University Press.

Lazaraton, A. (2000). Current trends in Research Methodology and Statistics in Applied Linguistics. TESOL Quarterly, 34(1), 175-181.

Loewen, S. Li, Fei, F., Thompson, A., Nakatsukasa, K., Ahn, S., \& Chen, X. (2009). L2 Learners' Beliefs about Grammar Instruction and Error Correction, Modern Language Journal, 93(1), 91-104.

Long, M. H. (1991). Focus on Form: A Design Feature in Language Teaching Methodology. In K.de Bot, R. Ginsberg, and C. Kramsch (eds.), Foreign Language Research in Cross-cultural Perspective. Amsterdam: John Benjamins.

Lyimo, A. J. (2008). Teachers' Use of Textbooks and Achievement of Curriculum Objectives: The Case of Social Studies Teaching in Three Primary Schools in Kinondoni District. M.A (Education) Dissertation, University of Dar es Salaam.

Maftoon, P., \& Shakouri, N. (2013). Relationship Between Learners' Beliefs System and the Choice of Language Learning Strategies: A Critical Study, International Journal of Research Studies in Language Learning, 2(2), 39-48.

Mantle-Bromley, C. (1995). Positive Attitudes and Realistic Beliefs: Links to Proficiency, Modern Language Journal, 79, 372-386.

McDonough, S. (1995). Strategy and Skill in Learning a Foreign Language. London: Edward.

Mohammad, S., \& Shokrpour, N. (2012). The Beliefs of Iranian ESP Students about Language Learning. Journal of Educational and Social Research, 2(3) 157-163.

Mori, Y. (1999). Epistemological Beliefs and Language Learning Beliefs: What do Language Learners Believe About their Learning?, Language Learning, 49(3), 377-415.

Ndulila, E. S. (2016). Tanzanian EFL Teachers' Perceptions and Attitudes towards Communicative Language Teaching (CLT): A Case Study of Secondary Schools in Morogoro Municipality, Unpublished M.A. (linguistics) Dissertation, University of Dar es Salaam.

Nikitina, L., \& Furuoka, F. (2007). Beliefs about Language Learning: A Comparison Between Novice and Intermediate Level Students Learning Russian at a Malaysian University. The Linguistics Journal, 2(1), 7-27.

Pajares, F. (1992). Teachers' Beliefs and Educational Research: Cleaning up a Messy Construct. Review of Educational Research, 62(3), 307-332.

Park, G. P. (1995). Language Learning Strategies and Beliefs about Language Learning of University Students Learning English in Korea. Unpublished Doctoral Dissertation, The University of Texas at Austin, USA.

Pazaver, A., \& Wang, H. (2009). Asian Students' Perceptions of Grammar Teaching in the ESL classroom. The International Journal of Language, Society and Culture, 27, 27-35. 


\section{Macrothink}

Journal for the Study of English Linguistics

ISSN 2329-7034

2018, Vol. 6, No. 1

Richards, J. C., Gallo, P. B., \& Renandya, W. A. (2001). Exploring Teachers' Beliefs and the Processes of Change. PAC Journal, 1(1), 41-58.

Riley, P. (1997). BATS' and 'BALLS': Beliefs about Talk and Beliefs About Language Learning, Mélanges CRAPEL, 23, 125-153.

Ruiz-Esparza, E. (2009). The Role of Beliefs about Assessment in a Bachelor in English Language Teaching Program in Mexico. Doctoral Dissertation, Macquarie University at Sydney, Australia.

Sakui, K., \& Gaies, S. J. (1999). Investigating Japanese Learners' Beliefs about Language Learning, System, 27, 473-492.

Saleh, A. (2012). Assessing Saudi Learners’ Beliefs about English Language Learning, International Journal of English and Education, 1(2) 31-55.

Shulman, L. S. (2005). Signature Pedagogies in the Professions. Daedalus, 134(3), 52-59.

Skinner, B. F. (1957). Verbal Behavior. Acton, MA: Copley Publishing Group.

Stevick, E. W. (1980). Teaching Languages: A Way and Ways. Rowley, MA: Newbury House Publishers, Inc.

Swain, M., \& Lapkin, S. (1995). Problems in Output and the Cognitive Processes they Generate: A Step Towards Second Language Learning. Applied Linguistics, 16, 371-391.

Tanaka, K. (2004). Changes in Japanese Students' Beliefs about Language Learning and English Language Proficiency in a Study-abroad Context. Unpublished $\mathrm{PhD}$ thesis, University of Auckland.

Tedick, D., \& de Gortari, B. (1998). Research on Error Correction and Implications for Classroom Teaching. The ACIE Newsletter, 1(3).

Turner-Bisset, R. (2001). Expert Teaching: Knowledge and Pedagogy to Lead the Profession. London, UK: David Fulton Publishers.

Victori, M., \& Lockhart, W. (1995). Enhancing Metacognition in Self-directed Language Learning, System, 23(2), 223-234.

Watson, J. B. (1930). Behaviorism. New York. Copley Publishers.

Wenden, A. (1999). An Introduction to Metacognitive Knowledge and Beliefs in Language Learning: Beyond the Basics [Special Issue]. System, 27, 435-441.

Wenden, A. L. (1986). Helping Language Learners Think about Learning. ELT Journal, 40(1), $3-12$.

White, C. (1999). Expectations and Emergent Beliefs of Self-instructed Language Learners. System, 27(4), 443-457.

Wideen, M., Mayer-Smith, J., \& Moon, B. (1998). A Critical Analysis of the Research on Learning to Teach: Making the Case for an Ecological Perspective on Inquiry. Review of 
Educational Research, 68(2), 130-178.

Williams, M. (1999). Learning teaching: A Social Constructivist Approach - Aheory and Practice or Theory with Practice. In H. Trappes-Lomax, \& I. McGrath (Eds.), Theory in Language Teacher Education (pp. 11-20). London, UK: Longman.

Williams, M., \& Burden, R. L. (1997). Psychology for Language Teachers: A Social Constructivist Approach. Cambridge: Cambridge University Press.

Williams, M., Burden, R., Poulet, G., \& Maun, I. (2004). Learners' Perceptions of their Successes and Failures in Foreign Language Learning, Language Learning Journal, 30, 19-29.

Woods, D. (2003). The social Construction of Beliefs in the Language Classroom. In P. Kalaja and A.M. Ferreira (eds.), Beliefs about SLA: New Research Approaches. Dordrecht: Kluwer Academic Publishers, 201-229.

Yang, N. D. (1999). The Relationship between EFL Learners' Beliefs and Learning Strategy Use. System, 27, 515-535.

Yoshida, R. (2013). Conflict between Learners' Beliefs and Actions: Speaking in the Classroom. Language Awareness. https://doi.org/10.1080/0009658416.2012.758129

Zhong, M. (2008). Report of a Pilot Study of the Beliefs of one Migrant Learner of English. Unpublished paper, Department of Applied language Studies and Linguistics, University of Auckland.

\section{Copyright Disclaimer}

Copyright for this article is retained by the author(s), with first publication rights granted to the journal.

This is an open-access article distributed under the terms and conditions of the Creative Commons Attribution license (http://creativecommons.org/licenses/by/3.0/). 